Eric Faure ${ }^{1}$

\title{
Did the Justinianic Plague Truly Reach Frankish Europe around 543 AD?
}

\begin{abstract}
But there are people who by a perversion of the intelligence do not believe what is written, find fault with what is witnessed by others, and even scorn as fraudulent what they themselves have seen. [...] I fear that I shall be criticised by some, who will say "You are a young man, so how can you

know about the deeds of those in the past? How has what they have done come to your knowledge? Surely the things that you have written can only be regarded as fictions made up by you"
\end{abstract}

\section{Introduction}

The word "plague" is used as a generic term for a scourge or an epidemic disease characterized by a high rate of mortality. However, for more than a century, it has principally referred to the disease caused by infection with the bacterium Yersinia pestis. There are three main clinical forms of this disease: bubonic, pneumonic and septicemic. Bubonic plague is the most common form and is characterized by one or more swollen, tender

\footnotetext{
1 Eric Faure, Professor, Aix-Marseille University, France; email: eric.faure@univ-amu.fr; ORCID: 0000-0003-2258-3991.

2 Gregorius Turonensis, Liber Vitae Patrum 17, tr. E. James, Gregory of Tours, Life of the Fathers, p. 104. This chapter describes, among other things, how the one living and two dead bishops of Trier protected their city from the plague: ,in the introduction [to this chapter], to guarantee to his readers the veracity of the hagiographic accounts of which he is the author, Gregory undertakes to expose systematically the criteria of authenticity that it requires from its sources, oral or written" (L. Pietri, La Vie des Pères, Paris 2016, p. 226, n. 317).
} 
and painful lymph nodes, called buboes, which occur in the thighs, neck, armpits or groin, and their increase in size renders them very visible ${ }^{3}$.

If epidemics in times of war or of famines are not considered, between the so-called plague of Cyprian, which was named after the bishop of Carthage who described the pandemic that struck the Roman Empire from c. 250 to c. $270 \mathrm{AD}^{4}$, and the beginning of the first documented pandemic of bubonic plague in history (541), very few epidemics occurred in the Roman and, later, Byzantyno-Roman Empires, which are the areas for which the data are the most numerous ${ }^{5}$. According to textual sources, this so-called first plague pandemic (c. 541 to c. 750 ) raged mainly along the Mediterranean Sea coasts and several epidemic outbursts occurred at irregular intervals ${ }^{6}$. The first episode is frequently called the Justinianic plague $^{7}$ (JP hereafter) after the Byzantine emperor who was reigning during this period and might even have contracted the disease but survived. The plague was first recorded in Egypt, and then it struck the Middle East, Asia Minor and Constantinople, which was ravaged in 542. According to some sources, this epidemic also reached Western Europe. An annotation in the so-called Latin chronicle of Zaragoza mentions it in Spain

\footnotetext{
P. Slack, Plague: a very short introduction, New York 2012, p. 5.

4 K. Harper, Pandemics and passages to Late Antiquity: Rethinking the plague of c. 249-70 described by Cyprian, "Journal of Roman Archaeology" 28 (2015) p. 223-260. Furthermore, all the dates mentioned in this article correspond to episodes that took place during the common era, so this indication will not be added hereafter.

5 D. Stathakopoulos, Famine and pestilence in the Late Roman and Early Byzantine Empire: A systematic survey of subsistence crises and epidemics, Aldershot 2016, p. 177-277.

6 For more recent data on the first plague pandemic, see e.g., M. Meier, The 'Justinianic Plague': The economic consequences of the pandemic in the eastern Roman empire and its cultural and religious effects, "Early Medieval Europe" 24 (2016) p. 267-292; K. Harper, The Fate of Rome: Climate, Disease, and the End of an Empire, Princeton 2017, p. 206-244, 339-344; M. Eisenberg - L. Mordechai, The Justinianic Plague: An Interdisciplinary Review, "Byzantine and Modern Greek Studies" 43 (2019) p. 156-180; K. Sessa, The New Environmental Fall of Rome: A Methodological Consideration, "Journal of Late Antiquity" 12 (2019) p. 211-255; M. Eisenberg - L. Mordechai, The Making of the Plague Concept: The Justinianic Plague, Global Pandemics, and Writing History, "American Historical Review" 125 (2020) p. 1632-1667; M. McCormick, Gregory of Tours on sixth-century plague and other epidemics, "Speculum" 96 (2021) p. 38-96.

7 The Justinianic plague and first plague pandemic are sometimes used as synonyms. In this study, the Justinianic plague (c. 541-549) only corresponds to the first part of the earliest of the three plague pandemics, see, e.g., L.A. White - L. Mordechai, Modeling the Justinianic Plague: Comparing hypothesized transmission routes, "PLoS One" 15/4 (2020) p. 1.
} 
in 542 or $543^{8}$, the Continuator of Count Marcellinus' Chronicle records a plague episode during the consulate year 542/543: „A great pestilence ravaged the land of Italy" , and several outbreaks in Frankish Europe were reported by Gregory of Tours (Gregory hereafter). Frankish Europe approximatively corresponds to Gaul, modern Belgium and the southwestern part of Germany. On both paternal and maternal sides, Gregory came from prominent Gallo-Roman families, several members of which had already distinguished themselves in the service of the $\mathrm{Church}^{10}$. He was born in Clermont, a city in the Auvergne region ${ }^{11}$ situated in central Gaul, in 538 or $539^{12}$. Gregory, while still very young and following a vow, entered the clergy of Clermont ${ }^{13}$. In 573, he was ordained bishop of Tours (center of the popular cult of St Martin), a ministry that he exercised until his death in $594^{14}$. Gregory lived during a troubled time when Gaul was torn by the rival ambitions of Germanic rulers and in addition to his investment in his ministry, he undertook writing books on the wars waged by the Germans and on saints and churchmen. The Ten Books of Histories (Decem Libri Historiarum) ( $\mathrm{LH}$ hereafter) which is sometimes incorrectly called History of the Franks, is his notable work but he was also the author of several hagiographical texts (Glory of the martyrs (GM hereafter), Suffering and miracles of the martyr St Julian (VJ), Life of the fathers (VP), Glory of the confessors $(G C)$ and four books entitled Miracles of the bishop St Martin $(\text { VM 1-4) })^{15}$.

Although Gregory was primarily interested in medicine to demonstrate the extent of the thaumaturgical powers of the saints, his writings reveal

8 Chronicorum Caesaraugustanum reliquae, Monumenta Germaniae Historica [MGH hereafter] Auct. Ant. 11, 2, p. 221-223, ad a. 542.

9 Marcellinus, Chronica, s.a. 543, MGH Auct. Ant. 11, 2, p. 107, 1. 11-12; tr. B. Croke, The Chronicle of Marcellinus: a translation and commentary, Oxford 2017, p. 50.

10 Pietri, La Vie des Pères, p. vii.

11 This name is derived from the Arverni, a Gallic tribe who once occupied the area.

12 R. Van Dam, Gregory of Tours, Glory of the Martyrs, Liverpool 2004, p. 108, n. 96.

13 Pietri, La Vie des Pères, p. 33.

14 According to Bruno Dumézil (La Reine Brunehaut, Paris 2008, p. 291), the arguments in favour of this date are quite fragile, and Gregory's death could be postponed or brought forward by one year. Otherwise, shortly after his death, Gregory was venerated as a saint in the towns of Tours and Clermont.

15 Latin text can be found in MGH, SSRM 1.1-2, online edition (https://www.dmgh. de, accessed 05.01.2021), and Pietri, La Vie des Pères. Gregory also wrote other works but which have not come down to us, except for a book intended to serve as a guide in determining the rhythm of nocturnal services (De cursu stellarum). 
that he had good knowledge of diseases as well as the remedies used to attempt to treat them ${ }^{16}$. In addition, he also mentions his rather good, it seems, relations with secular physicians, although he believed that only a saint could be a "true physician" (verus medicus) ${ }^{17}$, and both the hagiographic writings and those with a more important historical dimension contain medical information. During the period in which Gregory lived, the health situation deteriorated, because of the persistent and lasting presence of malaria ${ }^{18}$ and largely due to the occurrence of several epidemics, including bubonic plague ${ }^{19}$. Moreover, during this period in Frankish Europe, Gregory is almost the only source of information and he provides relatively detailed descriptions of some episodes.

For approximately half a decade, a stimulating but controversial debate has opened about the consequences of the first plague pandemic. Briefly, advocates of the maximalist hypothesis suggest that the mortality rate of the first pandemic was very high ${ }^{20}$, while the proponents of the revisionist view, who base themselves mainly on series of proxy data, argue that this pandemic did not caused a widespread demographic decline and therefore had few mid- to long-term effects ${ }^{21}$. The present article focuses on a critical analysis of the descriptions of the first epidemic outbursts of bubonic plague recorded in Frankish Europe by Gregory. The more precise aims of this study are to explore the construction of narrative discourse concerning the plague, to try to determine, the chronology of repetitions of this subject in the texts from one book to another and to propose dates for epidemic

16 A. Marignan, La Médecine dans l'Eglise au sixième siècle, Paris 1887; L. Pietri, Les médecins dans la Gaule chrétienne du Ve au VIIe siècle: rôle et réputation, "Annales Littéraires de l'Université de Besançon" 404 (1989) p. 343-357.

17 Gregorius Turonensis, Libri quattuor de Virtutibus Sancti Martini Episcopi II 52, ed. MGH SSRM 1/2, p. 177, 1. 5.

18 É. Faure - N. Jacquemard, L'émergence du paludisme en Gaule: analyse comparée des écrits de Sidoine Apollinaire et Grégoire de Tours, "Caesarodunum" 44-45 (2014) p. 55-70; É. Faure, Datation de l'introduction du paludisme en Provence, "Provence Historique" 67 (2017) p. 378-406; É. Faure, The Vita, the first testimony of the settlement of malaria in Provence, in: Caesarius of Arles and the Five Continents, v. 2, Venelles 2018, p. 217-225.

19 McCormick, Gregory of Tours.

20 E.g., Meier, The 'Justinianic Plague'; Harper, The fate of Rome.

21 L. Mordechai - M. Eisenberg, Rejecting catastrophe: The case of the Justinianic Plague, "Past Present" 244 (2019) p. 3-50; L. Mordechai - M. Eisenberg - T. Newfield, The Justinianic Plague: An inconsequential pandemic?, "Proceedings of the National Academy of Sciences" 116 (2019) p. 25546-25554. 
episodes. The study fits in part with the aforementioned debate because it provides information on the reliability to be assigned to Gregorian mentions of the first plague pandemic.

\section{Analysis of the plague episodes presumably dated around 543 mentioned by Gregory of Tours}

\subsection{Through penitential rogations instituted by St Gallus, bishop of Clermont, the people of his episcopal city were spared from the plague}

Gallus (c. 486-551) was bishop of Clermont from 525/526 until his death $^{22}$. In $V P$, Gregory included the Vita of this saint, who was also his paternal uncle ${ }^{23}$, and Gregory insisted on his religious vocation from adolescence, his course in orders, his relationship with Frankish powers and the great miracles that God performed through him during his lifetime and post-mortem; however, the liturgical dimension of this personage is almost absent. Gregory discussed at some length how Gallus, thanks to his piety, made his episcopal city safe from the plague:

When the epidemic that we call inguinaria raged in several regions, and above all ravaged the province of Arles, St Gallus [...] prayed to the Lord day and night [ $\ldots$ and an angel of the Lord said:] 'Your prayer has been heard, and you people are going to be delivered from the plague (infirmitate). None in this region shall die of it while you are alive. Do not be afraid now, but after eight years, be afraid'. From which it was clear that after this time he would leave this world. [... Gallus instituted mid-Lent rogations that led the devouts on foot over 60 kilometers which separates Clermont from the basilica of Brioude where the martyr Julian was venerated .... . And while the plague (lues) raged elsewhere, as we have said, the Arverne city, by the prayers of St Gallus, was exempt ${ }^{24}$.

22 L. Pietri - M. Heijmans, Prosopographie chrétienne du Bas-empire 4, GALLVS 3, Paris 2013, p. 849-853.

23 Gregorius Turonensis, Vitae Patrum 6, 1, ed. Pietri, La Vie des Pères, p. 71, n. 95.

24 Gregorius Turonensis, Vitae Patrum 6, 6, tr. James, Life of the Fathers 6, 6, p. 3940; cf. also Pietri, La Vie des Pères, p. 84, n. 105. 
This last passage is repeated almost verbatim in $L H$ (Table 1), suggesting the importance that Gregory attached to it. According to Robert Latouche ${ }^{25}$, the original text was from $V P$, and it would then have been included in $L H$.

\begin{tabular}{|c|c|}
\hline $\begin{array}{c}\text { Life of the Fathers }(V P \text { 6, 6) MGH } \\
\text { SSRM 1/2, p. 234, l. 15-28, p. 235, l. 1-2 }\end{array}$ & 138, 1. 8-25 \\
\hline $\begin{array}{l}\text { "Cum autem lues illa quam ingui } \\
\text { vocant per diversas regiones des } \\
\text { et maximae tunc Arelatensim prov } \\
\text { depopularet, sanctus Gallus non } \\
\text { pro se quantum pro populo suo tr } \\
\text { erat. Cumque die noctuque Domin } \\
\text { precaretur, ut vivens plebem suam } \\
\text { non cerneret, per visum noctis appa } \\
\text { angelus Domini, qui tam caesariem } \\
\text { vestem in similitudine nivis candida } \\
\text { rebat et ait ad eum: 'Bene enim te, o } \\
\text { dos, prospectat divina pietas pro pop } \\
\text { supplicantem; ideoque ne timeas, ex } \\
\text { est enim oratio tua; et ecce eris cum } \\
\text { tuo ab hac infirmitate liberatus, nul } \\
\text { te vivente, in regione ista ab hac stro } \\
\text { periet. Nunc autem noli metuere; po } \\
\text { vero annos time'. Unde manifestu } \\
\text { transactis his annis eum a saeculo } \\
\text { sisse. Expergefactus autem et Deo } \\
\text { pro hac consolatione agens, quoc } \\
\text { per caelestem nuntium confortare di } \\
\text { est, rogationes illas instituit, ut medi } \\
\text { dragesima psallendo ad basilicam b } \\
\text { liani martyris itinere pedestri veniren } \\
\text { autem in hoc itenere quasi stadia } 36 \\
\text { Cum autem regiones alias**, ut d } \\
\text { lues illa consumeret, ad civitatem Arv } \\
\text { sancti Galli intercedente oratione, no } \\
\text { git. Unde ego non parvam censeo g } \\
\text { qui hoc meruit, ut pastor positus, ove } \\
\text { devorari, defendente Domino, non vio }\end{array}$ & $\begin{array}{l}\text { "Huius tempore cum } \\
\text { riam vocant per dive } \\
\text { et maxime tunc Are } \\
\text { popularet, sanctus } \\
\text { quantum pro populc } \\
\text { mque die noctuque } L \\
\text { vivens plebem suam } \\
\text { visum noctis apparu } \\
\text { tam caesariem quam } \\
\text { nivis candidam effer } \\
\text { enim facis, o sacerdo } \\
\text { populo tuo supplicas } \\
\text { tua; et ecce! eris cu } \\
\text { firmitate liberatus, } n \\
\text { gione ista ab hac strc } \\
\text { ne timeas; post octo } \\
\text { manifestum fuit, trc } \\
\text { a saeculo discessisse } \\
\text { Deo gratias pro hac } \\
\text { eum per caelestem } \\
\text { gnatus est, rogatione } \\
\text { quadragesima psall } \\
\text { Iuliani martyris itine } \\
\text { autem in hoc itinere } \\
\text { Tunc etiam in subita } \\
\text { vel domorum vel ecc } \\
\text { tur, unde a rusticis hic } \\
\text { Cum autem regione } \\
\text { illa consumeret, a } \\
\text { sancti Galli interced } \\
\text { git. Unde ego non } 1 \\
\text { ai } \text { hom mo }\end{array}$ \\
\hline
\end{tabular}

Table 1. Strict similarities between the two passages mentioning how Clermont escaped to plague thanks to Gallus are in bold letters. *not present in all of the manuscripts (MS hereafter); **illas in Ms $1 \mathrm{a} ;{ }^{1}$ cerneret and ${ }^{2}$ simulitine in Ms $\mathrm{B} ;{ }^{3}$ alias in Ms D2. The words and part of a word also found in GM 50 are underlined.

25 Gregorius Turonensis, Decem Libri Historiarum IV 5, ed. Latouche, Grégoire de tours, Histoire des Francs, p. 184, n. 9. 
According to Michael McCormick ${ }^{26}$, it is difficult to precisely determine the year of arrival of the plague in Gaul because the date of 543 (or 544) is uncertain and he proposes a range of dates from 543 to $547^{27}$. Indeed, the date of 543 is based on a prophecy indicating that Gallus would die eight years after the plague outbreak knowing that it is traditionally accepted that he died in 551. However, McCormick considers that the direct successor to the episcopate of Clermont, Cautinus, could not have been elected until 555. In that year, Cautinus intrigued for the priest Cato to become the successor of Gonthier, bishop of Tours, who had just died. If it is considered that Cautinus had wanted to drive away a serious contender for the bishopric of Clermont, this could suggest that Gallus had recently died. However, Cautinus was already bishop at the time (Cautini episcopi $)^{28}$ and he certainly wanted to get rid of his unfortunate competitor for the previous election to the bishopric which bothered him ${ }^{29}$. It is true that there could be doubts as to the year of Gallus' death, especially since the date of Cautinus' episcopal consecration is not known. Gregory only mentions it after someone announced Gallus' death, ,the King [Theudebald] and his officials [...] summoned a council of bishops in the city of Metz. Cautinus the Archdeacon was elected to the episcopate" 30 . However, Gregory notes that Gallus passed away in the twenty-seventh year of his episcopate ${ }^{31}$, which corresponds to $26 \mathrm{com}$ pleted years $^{32}$ and he became bishop after Quintianus' death $(525 / 526)$ with a transition period between the two bishops that does not seem to have been very long ${ }^{33}$. Therefore, it appears preferable to keep 551 and $543^{34}$ as the year of Gallus' death and the year in which he instituted rogations due to the plague, respectively.

26 McCormick, Gregory of Tours, p. 67.

27 Riché dated this plague of the year 546 (Problèmes de démographie historique du Haut Moyen Age (Ve-VIIIe siècles), "Annales de démographie historique" 3 (1966) p. 47) and many authors in the $19^{\text {th }}$ century proposed, without trully giving any justification, 549, e.g., E. Dupouy, Le Moyen âge medical, Paris 1888, p. 53.

28 Gregorius Turonensis, Decem Libri Historiarum IV 11, ed. MGH SSRM 1/1, p. 141, 1. 14 .

29 McCormick, Gregory of Tours.

30 Gregorius Turonensis, Decem Libri Historiarum IV 7, tr. Thorpe, Gregory of Tours: History of the Franks, p. 201-202.

31 Gregorius Turonensis, Vitae Patrum 6, 7, ed. James, Life of the Fathers, p. 40.

32 Gregorius Turonensis, Vitae Patrum 6, 7, ed. Pietri, La Vie des Pères, p. 85, n. 5.

33 Gregorius Turonensis, Vitae Patrum 6, 3.

34 Even if 544 remains plausible. 
The Vita of St Gallus written by Gregory seems, as far as it is possible to judge, to follow the chronology of events but in the chapter preceding the mention of the epidemic it is reported a great assembly of bishops which likely occurred in $549^{35}$, suggesting a later insertion. Analysis of the preceding and following $L H$ chapters concerning this plague episode also raises chronological issues. The penultimate chapter of book III (no. 36) reports the death of King Theudebert which is dated 548. Book IV begins with the death of Queen Clotild (in 544), and at the end of chapter 3, the death of Injuriosus, Bishop of Tours, is mentioned (about 546). Chapter 4 ends with the mention of the death of his successor (about 552). Chapter 5 begins with the accession of Gallus to the bishopric of Clermont $(525 / 526)$ following the death of his predecessor, followed by the long development of the plague episode (543?), and end with Gallus' death (551?). The next two chapters (no. 6 and 7) address the accession to the episcopate of Cautinus. From chapter 8, several chapters concern an almost exclusively secular history with the assassination of Spanish King Agila and then the accession to the throne of Athanagild (554), the Byzantine victory at the battle of Volturno in Italy (554), and then the death of King Franc Theudebald (555). The presence of chapter 5 seems rather incongruous since it addresses events mainly taking place from 525 to 543 in the midst of others dating from the 550s. Latouche ${ }^{36}$ mentioned that chapters 5 to 7 , which mainly report only very local events, could have been added late, which could explain the chronological inconsistencies. Furthermore, the first sentence of chapter 5 begins with: „When, as I have above related, the blessed Quintianus had passed from this world" 37 , but Ormonde M. Dalton underlined: „This is not exact. Gregory has mentioned, bishop of Clermont, in III.2 and 12, but has said nothing of his death. This he

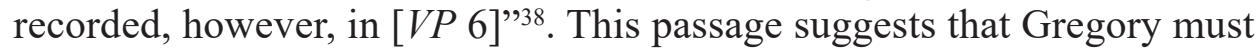
have forgotten that he had previously written in $L H$ and therefore favours a late addition as well.

In the diocese of Clermont, before the plague episode, rogations normally occurred after Easter but probably due to the gravity of the situa-

35 Gregorius Turonensis, Vitae Patrum 6, 5, ed. James, Life of the Fathers, p. 38, n. 17.

36 Gregorius Turonensis, Decem Libri Historiarum IV 5, ed. Latouche, Histoire des Francs, p. 184, n. 8.

37 Gregorius Turonensis, Decem Libri Historiarum IV 5, tr. Dalton, The History of the Franks, p. 119.

38 Gregorius Turonensis, Decem Libri Historiarum, ed. Dalton, The History of the Franks, p. 516. 
tion, Gallus had moved forward the date to mid-Lent ${ }^{39}$, suggesting therefore that the plague still raged at this time. In another hagiographic text, a sentence recalls the miracle accomplished through Gallus' intercession: „When the epidemic of inguinal plague approaching the Arverne region, that which was stopped thanks to the prayers of the bishop Saint Gallus $[\ldots]^{\prime 40}$. Considering this text and the route of the rogations, in addition to Clermont, at least a large part of the Arverne region ${ }^{41}$ had to be free from plague. Contrary to what this last passage suggests, $V P$ 6, 6 and $L H$ IV, 5 emphasize, without minimizing the role of Gallus, the determining role played by St Julian. However, in the Vita of this last saint written by Gregory $(V J)$, while the greatest miracle accomplished by his intercession would have been that which enabled the diocese of Clermont to escape the plague, it is not in any way mentioned, not even through allusion. Moreover, in this work, an entire chapter is devoted to Gallus ${ }^{42}$, in which it is detailed how Gallus, who was not yet bishop, was cruelly wounded by a thorn that had sunk into his foot and was miraculously delivered from this discomfort after having prayed at St Julian's tomb, located in Brioude. However, while the digressions are numerous in Gregory's works, such as the quite derisory anecdote quoted, he remains silent concerning the rogations to Brioude during the plague of 543. A mention of inguinal plague is however made in $V J^{43}$, but it concerns the epidemic that devastated Auvergne in 571, among other places ${ }^{44}$. During this episode, Gregory, who was still only deacon ${ }^{45}$, fled to Julian's protection at Brioude. He had likely left Lyon which was one of the cities heavily affected by the plague, but Gregory does not take advantage of this context to recall how St Julian protected Clermont in 543. Luce Pietri ${ }^{46}$ mentioned that VP 6 was composed or started after GM 50 and $V J 23$ and the analysis presented above therefore makes it possible to propose the following order of composition: $\left(1^{\text {st }}\right) V J 23,\left(2^{\text {nd }}\right) G M 50,\left(3^{\text {rd }}\right) V P$ 6 and $\left(4^{\text {th }}\right) L H$ IV, 5. The $V J$ would have been completed during the early

39 Gregorius Turonensis, Vitae Patrum 4, 4, ed. James, Life of the Fathers, p. 26, n. 17; Gregorius Turonensis, Vitae Patrum 6, 7, ed. James, Life of the Fathers, p. 39, n. 21.

40 Gregorius Turonensis, De Gloria Martyrum 50, 3, tr. Pietri, La Gloire des Martyrs, p. 159.

41 This area corresponds approximately to the Auvergne region.

42 Gregorius Turonensis, Liber de Passione et Virtutibus Sancti Iuliani Martyris 23, ed. Van Dam, Saints and their Miracles in Late Antique Gaul, p. 179.

43 Gregorius Turonensis, Sancti Iuliani Martyris 46a.

44 Gregorius Turonensis, Decem Libri Historiarum IV 31.

45 Gregorius Turonensis, Sancti Iuliani Martyris 46a, ed. Van Dam, Saints, p. 191, n. 30.

46 Pietri, La Vie des Pères, p. xxxvi. 
$580 \mathrm{~s}^{47}$, and the omission of mention of the epidemic of 543 in this work and especially in the paragraphs addressing Gallus, along with the record of the plague of 571, would tend to suggest that the first mention of the episode of plague of 543 in Gregory's work dates back to the mid-580s. In addition, Venantius Fortunatus (c. 530-609), who would likely have been inspired by the Vita written by Gregory to compose his poem dedicated to Gallus ${ }^{48}$, did not mention the plague epidemic either (the version read by Fortunatus should not mention this episode); however, unlike the Vitae that he himself wrote, Fortunatus placed little importance on miracles and diseases in his poems. Furthermore, Gregory indicated that in 543, other regions of Gaul were affected by the plague, but he only specifies the province of Arles, insisting that the epidemic would have severely raged there ${ }^{49}$. However, the Vita of Caesarius of Arles contradicts Gregory's claims. Caesarius was Bishop of Arles from 502 to 542 and the writing of his vita began shortly after his death and ended between 547 and $549^{50}$. This vita, which was written by three bishops, as well as a priest and a deacon, mentions no epidemic and only cases of non-plague individual diseases miraculously cured ${ }^{51}$.

\subsection{Bishop Cautinus, a life the opposite of that of his direct predecessor Gallus even during plague episodes}

The writings mentioning the plague that allegedly raged around 543 especially in Auvergne cannot be understood without analysing the life of Gallus' successor at the bishopric of Clermont: Cautinus. The theme that the "Life" of Gallus illustrates, ,is that of the necessary subversion of the ephemeral false values prevailing in the world here below, such as it is operated by those who want to live as Christians in order to acquire the only real lasting goods of the sky" ${ }^{\prime 2}$, while that of Cautinus is diametrically opposed. The portrait of Cautinus painted by Gregory is indeed very unflattering, e.g.

47 Van Dam, Saints, p. 163.

48 Venantius Fortunatus, Opera Poetica IV 4, ed. MGH Auct. Ant. 4/1, Berolini 1881, p. 81-82; cf. Pietri, La Vie des Pères, p. 68, n. 92.

49 Pietri, La Vie des Pères 6, 6, p. 83.

50 W.E. Klingshirn, Caesarius of Arles: The making of a Christian community in Late Antique Gaul, Cambridge 2014, p. 7; M.-J. Delage, Vie de Césaire d'Arles, Paris, 2010, p. 21.

51 Faure, Datation de l'introduction du paludisme en Provence, p. 378-406; Faure, The Vita, the first testimony of the settlement of malaria in Provence, p. 217-225.

52 Gregorius Turonensis, Vitae Patrum 6, 1, tr. Pietri, La Vie des Pères, p. 69, n. 93. 
Once he had taken possession of his bishopric, Cautinus began to behave so badly that he was soon loathed by everybody. He began to drink heavily. $\mathrm{He}$ was often so completely fuddled with wine that it would take four men to carry him from the table. Later on, no doubt because of his excesses, he became subject to epileptic fits. All this often occurred in full public view. What is more, he was so avaricious that it was a source of great anguish to him if he failed to transfer to himself some part of any territory which was adjacent to his own. [...] Nothing was sacred to Cautinus and he respected nothing. He had no time for literature, either sacred or profane ${ }^{53}$.

Moreover, Cautinus also committed an abomination that even "Nero and Herod" would never have done, i.e., burying a living man (in this case, a priest $)^{54}$. Similar to Gallus and in the time of year instituted by the latter, Cautinus organized rogations from Clermont to Brioude for political and not health reasons ${ }^{55}$, and Gregory insisted on the twists and turns of this trip, which was in fact inglorious for Cautinus. Perhaps thinking that readers might consider that he was forcing the line, Gregory added at the end of the chapter:

As I tell you this story, I cannot help thinking of what Sallust said about those who criticize historians: 'Writing history seems a difficult job: in the first place because what you put down has to correspond exactly to the facts; and secondly because if you permit yourself to criticize any wrongdoing, most of your readers think that you are being malevolent, or even envious ${ }^{56}$.

According to Latouche ${ }^{57}$, this last sentence was included in a chapter (no. 13) that was added to the final draft suggesting that it might be a Gregory's attempt at justification.

The sentence concerning Gallus, ,As long as you live, you and your flock will be free of the plague and no one in this region will die because

53 Gregorius Turonensis, Decem Libri Historiarum IV 12, tr. Thorpe, History of the Franks, p. 204-205, 207.

54 Gregorius Turonensis, Decem Libri Historiarum IV 12, ed. Thorpe, History of the Franks, p. 207.

55 Gregorius Turonensis, Vitae Patrum 6, 6, ed. James, Life of the Fathers, p. 39, n. 21.

56 Gregorius Turonensis, Decem Libri Historiarum IV 13, tr. Thorpe, History of the Franks, p. 208-209; citation from Sallust, Catilina 3.

57 Gregorius Turonensis, Decem Libri Historiarum IV 13, tr. Latouche, Histoire des Francs, p. 193. 
of it" ${ }^{\prime 58}$, can only be understood by reading the vicissitudes of his successor at the bishopric of Clermont. Indeed, Cautinus' episcopate ended in an epidemic from which he died, and the end of his life was also the opposite of that of Gallus. During the pestilence episode, Cautinus abandoned his bishopric and travelled to various places in an attempt to escape it, but it finally caught him on his return to Clermont, and he died from $\mathrm{it}^{59}$. At midLent, Gallus (with St Julian's help) saved Clermont and its region from the plague ${ }^{60}$, while under Cautinus' episcopate, the city was devastated, and Gregory mentions that he died on Good Friday ${ }^{61}$ (27 March for 543), suggesting, although not mentioned by Gregory, a parallel with the "unrepentant thief" of the Holy Scriptures ${ }^{62}$. Moreover, his cousin Tetradius also died at the same hour ${ }^{63}$. In addition, the two mentions of Cautinus' death are very succinct. For example, in $L H \mathrm{IV}, 35$, the comment is even more brief: „Now when, as I told you, Bishop Cautinus died in Clermont, many put themselves forward for the episcopate" ${ }^{64}$. The contrast with Gallus is very great, as Gallus died on a Sunday after having celebrated the mass and with the great pomp of his funeral spread over several days, in which the bishops of the province assisted ${ }^{65}$.

In Gregory's works, four passages mention the plague that raged during Cautinus' episcopate ${ }^{66}$ and he recorded twice that it was an inguinal plague episode of which he was an eyewitness ${ }^{67}$. This epidemic devastated Auvergne in 571 as well as large cities of central Gaul and a detailed analysis of this episode was recently undertaken by $\mathrm{McCormick}^{68}$. In contrast to the near absence of data concerning the plague itself in 543 which, however, would not have reached Clermont, many precise details are provided

58 Gregorius Turonensis, Decem Libri Historiarum IV 5, tr. Thorpe, History of the Franks, p. 200.

59 Gregorius Turonensis, Decem Libri Historiarum IV 31.

60 Gregorius Turonensis, Vitae Patrum 6, 6.

61 Gregorius Turonensis, Decem Libri Historiarum IV 31.

62 Luke 23:39-43.

63 Gregorius Turonensis, Decem Libri Historiarum IV 31.

64 Gregorius Turonensis, Decem Libri Historiarum IV 35, tr. Thorpe, History of the Franks, p. 229.

65 Gregorius Turonensis, Vitae Patrum 6, 7, ed. James, Life of the Fathers, p. 40-41.

66 Gregorius Turonensis, Decem Libri Historiarum IV 31-32; Gregorius Turonensis, Sancti Iuliani Martyris 46a; Gregorius Turonensis, Vitae Patrum 9, 2.

${ }_{67}$ Gregorius Turonensis, Vitae Patrum 9, 2, ed. MGH SSRM 1/2, p. 254, 1. 1; Gregorius Turonensis, Sancti Iuliani Martyris 46a, ed. MGH SSRM 1/2, p. 132, 1. 3.

68 McCormick, Gregory of Tours, p. 75-79. 
for that in 571, such as the number of dead corpses counted in the basilica of Clermont in a single day, the lack of coffins and tombstones, and ten or more bodies buried in the same grave ${ }^{69}$. Similarly, at the symptomological level, Gregory also provides details:

Death came very quickly. An open sore like a snake's bite appeared in the groin or the armpit, and the man who had it soon died of its poison, breathing his last on the second or third day. The virulence of the poison made the victim unconscious ${ }^{70}$.

Many of Gregory's historical narratives are nourished by the opposition between those who engaged in behaviours that tended toward the Christian ideal, with the saints being the earthly models to follow, and others whose actions diverted them from this ideal ${ }^{71}$. Cautinus' character was likely disreputable, and since Gregory was writing relatively soon after Cautinus' death, his description of him must, at least in large part, correspond to reality. However, Gregory takes great care in his writing to build, in almost all points, a portrait in antithesis to his uncle Gallus. One is intended to arouse admiration in readers, and the other, contempt. Both were bishops of the same city with one having directly succeeded the other. The contrast is even more striking, and Cautinus' attitude during the plague episode is also the opposite of the behaviour attributed to Gallus on the same occasion. An epidemic having occurred in 571 seems very credible as the following three points suggest: first, a mention of the chronicle of Marius bishop of Avenches (532-596) seems to corroborate this episode ${ }^{72}$; second, Gregory provides very precise details, such as the number of dead counted during a Sunday in Clermont and the material difficulties related to the funeral; and finally, Gregory, even if he was not in Clermont at that time, was a direct witness of this epidemic episode and indicated that during this outbreak, he went to Brioude to place himself under the protection of St Julian, which does not implicitly seem very rewarding for him (but is imbued with sincerity and adds credibility to the episode) because he could have fled Lyons to attempt to escape the

69 Gregorius Turonensis, Decem Libri Historiarum IV 31.

70 Gregorius Turonensis, Decem Libri Historiarum IV 31, tr. Thorpe, History of the Franks, p. 226.

71 M. Heinzelmann, Structures typologiques de l'histoire d'après les histoires de Grégoire de Tours, "Recherches de Science Religieuse" 92 (2004) p. 569-596.

72 Marius Aventicensis, Chronica, s.a. 571, ed. Favrod, La Chronique de Marius d'Avenches (455-581), p. 82-83. 
plague in a behaviour similar to that of Cautinus, except that Gregory was not in charge of a diocese at the time ${ }^{73}$.

Otherwise, in the plague mentions of 543, there is no record of the notion of sin, unlike the one during the epidemic of 571: „Because the people's sins were excessive, during the episcopacy of Cautinus, the territory of Clermont was devastated by a ruinous plague that the people call the plague of the groin" ${ }^{74}$. Gregory therefore suggests that the flock of the execrable Cautinus was in his image. For episodes around 543 , mentioning the flocks' sins would have discredited the bishops of the dioceses of Clermont and Trier (see below), who were future saints. Furthermore, in $L H$, unlike the chapter mentioning the plague around 543 , those describing the plague of $571^{75}$ were probably already present in the first version of $L H$.

\subsection{Gregory's mother and the mysterious appearance of signs during the plague episode around 543}

Twice in Gregory's corpus - once in a hagiographic text and again in $L H$ - it is mentioned that, during the first outbreak of the plague, mysterious marks appeared on constructions in Auvergne. The longest description is found in GM and involves Gregory's mother, Armentaria:

When that plague of the groin that the prayer of the bishop St Gallus [eventually] repulsed was approaching the territory of Clermont, signs and marks appeared on the walls of homes and churches suddenly, as men looked. My mother had a vision during the night in which it seemed that the wine that was in our cellars had been changed into blood. She wept and said: 'Woe am I, because my house has been marked for the plague'. A man replied to her and said: 'Do you know that the [anniversary of the] suffering of the martyr Benignus will be celebrated tomorrow on the Kalends of November [1 November]?' 'I know', my mother said. He said: 'Go, keep the vigil in his honor during the entire night, celebrate mass, and you will be rescued from the plague'. My mother awoke from her sleep and did what she had

73 He was deacon. Gregorius Turonensis, Sancti Iuliani Martyris 46a, ed. Van Dam, Saints, p. 191-192, n. 30.

74 Gregorius Turonensis, Sancti Iuliani Martyris 46a, tr. Van Dam, Saints, p. 191, n. 30.

75 Gregorius Turonensis, Decem Libri Historiarum IV 31-32. 
been ordered. Although the houses of our neighbors were marked, our home remained untouched ${ }^{76}$.

In $L H$, Gregory records this episode using only a few words (Table 1 ); however, the nature of the marks is specified here. During the rogations from Clermont to Brioude undertaken by Gallus to ward off the plague, ,The suddenly as men looked, signs appeared on the walls of the houses and churches, which writing was called Tau by the people" 77 .

Most of the text presented in $L H$ is identical to a part of that found in $G M$ (the terms, and part of one of them, retained appear in bold letters):

,$[\ldots]$ et in subita contemplatione parietes domorum atque* ecclesiarum signarentur, atque caraxarentur, $[. .$.$] "78$

„Tunc etiam in subita contemplatione parietes vel domorum vel ecclesiarum signari videbantur, unde a rusticis hic scriptos Thau vocabatur"79

In $L H$, this passage was inserted within the long text that came from $V P^{80}$ (Table 1), supporting the hypothesis that during the last modifications made to $L H$, Gregory recopied information from his hagiographic texts, sometimes almost verbatim. What reinforces this assumption is that the nature of the sign (Thau, or less often, Tau ${ }^{81}$ did not appear in the text of $G M$, although it was much longer. Gregory could have brought his $L H$ to a close between April and August 59482.

76 Gregorius Turonensis, De Gloria Martyrum 50, 3, tr. Van Dam, Glory of the Martyrs, p. 51.

77 Gregorius Turonensis, Decem Libri Historiarum IV 5, tr. Dalton, The History of the Franks, p. 119.

78 Gregorius Turonensis, De Gloria Martyrum 50, ed. MGH SSRM 1/2, p. 74, 1. 1-2; *omitted in some Mss.

79 Gregorius Turonensis, Decem Libri Historiarum IV 5, ed. MGH SSRM 1/1, p. 138, 1. 21-22.

80 Gregorius Turonensis, Vitae Patrum 6, 6.

81 Gregorius Turonensis, Decem Libri Historiarum IV 5, ed. MGH SSRM 1/1, p.138, n. o.

${ }^{82}$ Pietri, La Gloire des Martyrs p. xiv. From information reported by Gregory himself, his health appears to have been weak (J. Verdon, Grégoire de Tours: le père de l'histoire de France, Roanne 1989, p. 59-62) and these latest changes were made only a few months before his death. 
There are doubts about the year of appearance of the mysterious signs described by Armentaria ${ }^{83}$ versus that of the rogations instituted by Gallus $^{84}$. In the literature, the two events are most often dated to the same year, $543^{85}$; therefore, Armentaria would have made her dream several months later than that of Gallus ${ }^{86}$. However, the reverse could be more likely. The passage detailing Gallus' dream ${ }^{87}$ emphasizes that the desired and obtained protection likely concerned all of the inhabitants of the diocese, which seems quite logical when the request comes from a virtuous bishop. This episode could be summarized as follow. While the inguinal plague raged in several regions, St Gallus trembled for his people (populo), and he begged the Lord that, during his lifetime, he would not see his people (plebem) decimated. The angel of the Lord said to Gallus that he and his people (populo) were going to be delivered from the disease and that none in this region would die of it while he was alive. After the rogations, while the plague raged elsewhere, the town of Clermont ${ }^{88}$ (civitatem Arvernam), by the prayers of St Gallus, was exempt. Further, Gregory concluded that it is not a small favour that this pastor merited not to have seen his flock (oves $=$ sheep) devoured since it was protected by the Lord. Only once was the town of Clermont mentioned; however, civitas could refer to a set of citizens and therefore could correspond here to the people of Auvergne or more likely to those of the diocese. At the time of this plague, Gregory and his family lived in Clermont or close to this city, and the passage concerning Armentaria's dream concludes with „Although the houses of our neighbors were marked [and presumably stricken by plague] our home remained untouched" 89 . From there, it can be deduced that since the diocese of Clermont would have been totally protected by the intercession of Gallus, the event described here would have occurred earlier, i.e., dated to

83 Gregorius Turonensis, De Gloria Martyrum 50.

84 Gregorius Turonensis, Vitae Patrum 6, 6; Gregorius Turonensis, Decem Libri Historiarum IV 5.

85 Cf., e.g., James, Life of the Fathers 6, 6, p. 39, n. 20; Van Dam, Saints, p. 45, 53 54; Van Dam, Glory of the Martyrs 50, p. 51, n. 62; A. Jones, Death and Afterlife in the pages of Gregory of Tours: Religion and society in Late Antique Gaul, Amsterdam 2020, p. 29-30, 44- 45 .

86 McCormick, Gregory of Tours, p. 69-70.

87 Gregorius Turonensis, Vitae Patrum 6, 6; Gregorius Turonensis, Decem Libri Historiarum IV 5.

88 However, at that time, to name this city Clermont is an anachronism.

89 Gregorius Turonensis, De Gloria Martyrum, tr. Van Dam, Glory of the Martyrs 50, p. 51 . 
the end of October 542. Note also that the passage concerning Armenteria would have been composed before that involving Gallus ${ }^{90}$.

Chapters 1 to 93 of GMwere mainly written from 584 to 590, and Gregory attempted, as much as possible, to respect the chronological sequence of major events ${ }^{91}$. Chapter 50 shows the process by which the cult of a martyr ${ }^{92}$ arises to be finally authenticated by the local ecclesiastical authority, the bishop of Langres (also named Gregory), who is none other than Gregory's maternal great-grandfather ${ }^{93}$. In this chapter, it is possible to at least to propose a chronological sequence, if not to date some events. There is first of all, twice the intervention of Gregory of Langres whose episcopate is dated from 507/508 to 539/540. Then, post-mortem miracles performed by St Benignus are listed. The last sentences of the paragraph on miraculous healings read: „I certainly experienced this. For when my eyes were severely inflamed, I was touched with this holy ointment and immediately lost the pain"94. Since Gregory indicated that he applied the miraculous ointment himself, this suggests that he was no longer a young child (e.g., he was only ten years old in 548/549). In addition, Gregory could have even applied this ointment when he was an adult ${ }^{95}$. The last paragraph of chapter 50 concerns the appearance of signs and Armentaria's dream, episodes that are dated to 542 (or less likely of 543). This departure from the chronology, which was quite respected in the chapter, could suggest that the last paragraph was added later.

Studies of the speed of diffusion in France of the Black Death in the $14^{\text {th }}$ century have shown that the plague progressed more quickly in summer and along major roads or down rivers, but it slowed either during cold weather or along secondary roads and over the rises of rivers ${ }^{96}$. The earliest zone affected in Gaul by the first plague epidemic is not mentioned by Gregory, but it is indicated twice that the province of Arles was particularly ravaged ${ }^{97}$, so

90 Pietri, La Gloire des Martyrs, p. xxxvi.

91 Pietri, La Gloire des Martyrs, p. x.

92 This concerns St Benignus who is probably an apocryphal martyr. Van Dam, Saints, p. 45; Van Dam, Glory of the Martyrs, p. 50, n. 60.

93 Gregorius Turonensis, De Gloria Martyrum 50, ed. Pietri, La Gloire des Martyrs, p. 154-158, n. 203-207.

94 Gregorius Turonensis, De Gloria Martyrum 50, tr. Van Dam, Glory of the Martyrs, 50, p. 51.

95 Gregorius Turonensis, De Gloria Martyrum 50, ed. Pietri, La Gloire des Martyrs 50, p. 159 , n. 208.

96 Biraben, Les hommes et la peste, p. 91.

97 Gregorius Turonensis, Vitae Patrum 6, 6; Gregorius Turonensis, Decem Libri Historiarum IV 5. 
it could have been the entry point. This city, located on the edge of the great river Rhone, is also close to the Mediterranean Sea and could be considered a river-sea port in classical antiquity ${ }^{98}$. An introductory route of plague by sea is a very plausible hypothesis; for example, in 588, a ship from Spain is thought to have brought inguinal plague to Marseilles ${ }^{99}$.

Although the major plague outbreak hotspots would be more dependent on major trade routes than on inland waterways ${ }^{100}$, as in south-eastern Gaul most trade and transportation was undertaken on the Rhone River, the plague would have diffused along the south-north axis of the Rhone to Lyon, which required going up the river (including a vertical drop of 150 $\mathrm{m}$ and opposing currents that could be strong) and then obliquely toward the west to go from Lyon in Clermont (these two towns are approximately at the same latitude) by following secondary communication routes, along which the average speed of propagation was slower. Based on the data provided by Ole J. Benedictow for the Black Death ${ }^{101}$, it can be estimated that it would have taken three months for the plague from Arles to Lyon and the same to cover the Lyon-Clermont route. According to this hypothesis, with the plague being mentioned in the region of Clermont at the end of October 542, it would have arrived in Arles during the month of April 542, but the epidemic did not strike Constantinople until this same month, and as the sea crossing from the capital of the Empire to Arles requiring approximately a month ${ }^{102}$, the spread of the plague would have occurred

98 S. Marlier, Le port d'Arles à l'époque romaine: un port fluviomaritime, "Archaeonautica" 18 (2014) p. 62-63. However, in the second half of the $5^{\text {th }}$ century, Arles was increasingly overwhelmed economically by its rival Marseilles, the port of which became one of the most important on the Mediterranean Sea (M. Heijmans, Arles durant l'antiquité tardive: de la duplex Arelas à l'urbs genesii, Rome 2004, p. 396); nevertheless, the arrival of the plague in Arles or Marseilles does not greatly modify the distance to be covered to reach Clermont.

99 Gregorius Turonensis, Decem Libri Historiarum IX 21-22; see M. McCormick, Bateaux de vie, bateaux de mort. Maladie, commerce, transports annonaires et le passage économique du bas-Empire au Moyen Âge, in: Morfologie sociali e culturali in Europa fra tarda Antichità e alto medioevo (Spoleto, 3-9 aprile 1997), Settimane di studio del centro italiano di studi sull'alto medioevo 45/1, Spoletto 1998, p. 35-122.

100 R.P. Yue - H.F. Lee - C.Y. Wu, Navigable rivers facilitated the spread and recurrence of plague in pre-industrial Europe, "Scientific Reports" 6 (2016) p. 34867.

101 O.J. Benedictow, The Black Death (1346-1353). The complete history, Woodbridge 2004, p. 227-233.

102 Orbis, this site allows for estimating the time needed to undertake different voyages in Antiquity by also choosing the season. 
from another eastern port ${ }^{103}$. In addition, to arrive in Arles during April, the trip had to start in March, which is a month that was still not very suitable for navigation ${ }^{104}$. For travel during the favourable sailing season, the sea crossing would have had to start between April and September $541^{105}$. According to Procopius ${ }^{106}$, the plague was first reported at the Egyptian port of Pelusium (potentially in mid-July 541) ${ }^{107}$. The plague would have then reached the Neguev cities, Gaza and Ashkelon in Palestine, and Alexandria of Egypt from mid-August to December $541^{108}$. Contamination of Gaul from a Middle Eastern port therefore remains possible, especially as suggested by Gregory, in his time, there was still very active importation of papyrus from Egypt ${ }^{109}$. According to Henri Pirenne ${ }^{110}$, papyrus, alongside spices, was one of the most important products of Mediterranean trade. Nevertheless, if the plague had arrived in Gaul in 541 before the period of the mare clausum, it would likely have been mentioned earlier in Clermont. Furthermore, a faster contamination, such as by an infected individual traveling by cart from the Gallic Mediterranean coast to Clermont, cannot be excluded, and according to this option, a ship that left an eastern Mediterranean port at the beginning of September 542 at the latest could have been at the origin of an epidemic in Auvergne at the end of October 542. Assuming that, at that time, the Maghreb was contaminated ${ }^{111}$, the ship, which was the most likely the means of dissemination of plague, could not have left until the end of September, but this scenario still assumes that inland Gaul was infected before Rome ${ }^{112}$.

Gallus and Armentaria were certainly the two individuals who Gregory loved the most, so it is no surprise that many similarities appear in his

103 The arrival of the plague from a western Mediterranean port (i.e., from Spain or Italy) seems unlikely given the date.

104 L. Casson, Ships and Seamanship in the Ancient World, Princeton 2014, p. $270-272$.

105 Casson, Ships and Seamanship in the Ancient World, p. 270.

106 Procopius, De Bello Persico II 6, tr. Dewing, p. 452-453.

107 Stathakopoulos, Famine and pestilence, p. 278.

108 Stathakopoulos, Famine and pestilence, p. 278-280.

109 Gregorius Turonensis, Decem Libri Historiarum V 5; Gregorius Turonensis, Libri quattuor de Virtutibus Sancti Martini Episcopi III 50; Gregorius Turonensis, De Gloria Martyrum 103; Gregorius Turonensis, Vitae Patrum 8.

${ }_{110} \mathrm{H}$. Pirenne, Le commerce du papyrus dans la Gaule mérovingienne, "Comptes Rendus des Séances de l'Académie des Inscriptions \& Belles-lettres” 72 (1928) p. 181.

111 Victor of Tunnuna, Chronica, MGH Auct. Ant. 11, p. 210, 1. 8-9.

112 Marcellinus, Chronica, s.a. 543, MGH Auct. Ant. 11/2, p. 107, 1. 11-12. 
descriptions of their lives ${ }^{113}$. The two paragraphs mentioning the divine intervention that ensured protection against the epidemic, are constructed in analogous manner. Due to the onset of the plague, Gallus and Armentaria were worried about his diocese and her house, respectively. One night, an angel of the Lord or an ordinary heavenly envoy appeared in a dream and spoke to the bishop and Gregory's mother, respectively. The words believed to have been spoken are fully transcribed. The bishop instituted rogations in mid-Lent from Clermont to Brioude while Armentaria, following the instructions given to her, celebrated the feast of St Benignus which were preceded by vigils. The saints involved in these two episodes are not just any saints but two tutelary saints of Gregory's family one from the father's side and the other from the mother's side ${ }^{114}$. Grateful devotion was vowed by Gregory's maternal family to St Benignus, as it was Gregory's great-grandfather who authenticated the tomb of the martyr and honoured his worship ${ }^{115}$. Through the intercession of this saint, Gregory even healed ophthalmia' ${ }^{116}$, while Gregory's paternal family patronized the cult of St Julian $^{117}$. In the end, both the diocese and Armentaria's house were preserved from the plague. Note that the bishop and Gregory's mother wanted to protect his diocese and her home, respectively, and that the first received a visit from a messenger of God, who was an angel for Gallus whereas for the second, the visit was from only a heavenly quidam. Moreover, Gallus and Armentaria are also said to have allowed fires to be extinguished. A very big fire which could have reduced to ashes the city of Clermont was extinguished thanks to the intercession of Gallus ${ }^{118}$, while Armentaria, thanks to the relics of saints, allowed the extinction of a fire in her own house $^{119}$ and of another which ravaged stacks of wheat ears, probably in

113 Gregory always had tender veneration for his mother (P. d'Hérouville, La culture classique de saint Grégoire de Tours, "Études des Pères de la Compagnie de Jésus" 126 (1911) p. 803) and after the death of Gregory's father, probably about 548 (M. Heinzelmann, Gregory of Tours: History and Society in the Sixth Century, tr. Carroll, Cambridge 2001, p. 29), Gregory was entrusted by his mother to Gallus, who paid him great attention (Gregorius Turonensis, Vitae Patrum II 2).

114 Cf. also Jones, Death and Afterlife in the Pages of Gregory of Tours, p. 30.

115 Gregorius Turonensis, Vitae Patrum 50.

116 Gregorius Turonensis, Vitae Patrum 50.

117 Van Dam (Saints, p. 45) notes that local aristocratic families formed cults dedicated to specific saints.

118 Gregorius Turonensis, Vitae Patrum 6, 6, ed. Pietri, La Vie des Pères, p. 83.

119 Gregorius Turonensis, Liber in Gloria Confessorum 3, ed. Van Dam, Gregory of Tours, Glory of the confessors, p. 4-5. 
the family domain ${ }^{120}$. As with the plague, for these last miracles performed through Bishop Gallus and the "venerable mother" 121 Armentaria, there is always a difference of degree but not of kind.

The word Thau (or Tau in two Mss) is a hapax in Gregory's works. In 1851, a German scholar ${ }^{122}$ first made a connection between Gregory's text and a passage from the Book of Ezekiel:

[9:4] And the Lord said to him: Go through the midst of the city, through the midst of Jerusalem: and mark Thau upon the foreheads of the men that sigh, and mourn for all the abominations that are committed in the midst thereof. [9:6] Utterly destroy old and young, maidens, children and women: but upon whomsoever you shall see Thau, kill him not, and begin ye at My sanctuary ${ }^{123}$.

Moreover, in his commentary of this book, Jerome noted:

According to the ancient form of the Hebrew letters, which the Samaritans still use, the last letter, Thau, resembles the cross [a X-shaped cross], which is formed on the foreheads of Christians, and is marked by the frequent signing with the hand ${ }^{124}$.

Tav or Taw is the last letter of most Semitic alphabets and could be written in the early alphabets as an X or similar to a Latin cross. The reconstructed name of this letter often meant mark or sign and more specifically, "owner's mark" in the Proto-Sinaitic alphabet ${ }^{125}$; therefore, the formulation "mark Thau" can be considered a pleonasm.

120 Gregorius Turonensis, De Gloria Martyrum 83, ed. Pietri, La Gloire des Martyrs, p. 244-247.

121 Gregorius Turonensis, Libri quattuor de Virtutibus Sancti Martini Episcopi I, 36, ed. MGH SSRM 1/.2, p. 155, 1.ine 15-16.

122 W. Giesebrecht, Gregor von Tours, Zehn Bücher Geschichten, v. 1, Berlin 1851, p. 184, n. 1 .

123 F.P. Kenrick, The book of Job, and the Prophets, tr. from the Vulgate, a revised ed. of the Douay version, Baltimore 1859, p. 487.

124 Kenrick, The book of Job, and the Prophets, p. 487, n. 5; see also G.L. Haydock, The Holy Bible; translated from the Latin vulgate, New York 1855, p. 1042, n. 4; R. Pummer, Early Christian Authors on Samaritans and Samaritanism: Texts, Translations and Commentary, Tübingen 2002, p. 190.

125 W.F. Albright, The Proto-Sinaitic inscriptions and their decipherment, Harvard 1969 , p. 9 b. 
According to Gregory, the mysterious signs appeared twice within a few months, which does not add credibility to the episode. Although it is only a question of conjuncture, since Gregory is silent on the nature of the signs in the text of $G M$, it is not until later, in the final additions to $L H$, that he mentions the precise nature of the signs indicating that rustici designated them by the word Thau. In Gregory's corpus, rusticus most often means rude, ignorant or simply commoner ${ }^{126}$, but it is unlikely that a vulgum pecus knew the book of Ezekiel. Max Bonnet suggested that clerics, based only on their knowledge of the Vulgate, could have proposed this name ${ }^{127}$.

McCormick underscores that the appearance of these marks on constructions could be due to a meteorological phenomenon called "blood rain", in which iron-rich dust from the Sahara Desert was transported by violent winds and later fell as rain on Southern Europe ${ }^{128}$. For the year 582, Gregory recorded, a similar phenomenon that was followed by epidemics:

In the Paris region real blood rained from a cloud, falling on the clothes of quite a number of people and so staining them with gore that they stripped them off in horror. This portent was observed in three different places in that city. In the Senlis area a man woke up one morning to find the whole of the inside of his house spattered with blood. This year the people suffered from a terrible epidemic; and great numbers of them were carried off by a whole series of malignant diseases, the main symptoms of which were boils and tumours. Quite a few of those who took precautions managed to escape. We learned that a disease of the groin was very prevalent in Narbonne this same year, and that, once a man was attacked by it, it was all up with him ${ }^{129}$.

126 M. Bonnet, Le latin de Grégoire de Tours, Paris 1890, p. 26; C. Carozzi, Grégoire de Tours historien?, in: Faire l'événement au Moyen Âge, ed. C. Carozzi - H. TavianiCarozzi, Aix-en-Provence 2007, p. 201-215.

127 Bonnet, Le latin de Grégoire de Tours, p. 26-27, n. 5; numerous quotes prove that Gregory had also good knowledge of the Vulgate (e.g., Bonnet, Le latin de Grégoire de Tours, p. 52-60). Otherwise, in many works of medieval religious art, such as in the $12^{\text {th }}$ century, the Tau sign was painted on doors, lintels or the foreheads of personages (É. Mâle, L'art religieux du XII siècle en France: étude sur les origines de l'iconographie du moyen âge, v. 1, Paris 1922, p. 156, 160, 163-165).

128 McCormick, Gregory of Tours, p. 69-70.

129 Gregorius Turonensis, Decem Libri Historiarum VI 14, tr. Thorpe, History of the Franks, p. 346. 
Gregory's narration also echoes that of Paul the Deacon (c. 720-c. 799), who mentioned that mysterious signs appeared one year before a plague outbreak:

For suddenly there appeared certain marks among the dwellings, doors, utensils, and clothes, which, if any one wished to wash away, became more and more apparent. After the lapse of a year indeed there began to appear in the groins of men and in other rather delicate places, a swelling of the glands, after the manner of a nut or a date $[\ldots]^{130}$.

This epidemic broke out in the province of Liguria, but it spread throughout Italy. For this outbreak, Paul the Deacon's text seems to refer to a period after 565, and the majority of authors link this epidemic to that mentioned by Marius of Avenches in 570-571 131 . Paul the Deacon wrote The History of the Lombards in the late $8^{\text {th }}$ century, but if the anecdote concerning the appearance of the signs was already circulating in Gaul in the 570s, Gregory could have also been inspired by it, all the more since he would not have started to write the GM not before $584^{132}$ or $585^{133}$. However, an alternative hypothesis can also be proposed: Paul the Deacon could have been inspired by Gregory, indeed, the $L H$ was an important source of information for Paul, especially for the events implicating the Franks in the third quarter of the $6^{\text {th }}$ century which corresponds to the $L H \mathrm{IV}^{134}$.

130 Paulus Diaconus, Historia Langobardorum II 4, tr. Foulke, p. 56-57. Note: several sources relate an analogous account during the last outbreak of the first plague pandemic in Constantinople (747-748, this is about four decades before Paul the Deacon began writing his major work). Here is what Theophanes the Confessor (c. 758/760-817) reports on this subject in his Chronicle (Chronographia, AM 6238) written during the years 810 to 815 : „All of a sudden, without visible cause, there appeared many oily crosslets upon men's garments, on the altar cloths of churches, and on hangings" (tr. C. Mango R. Scott, The Chronicle of Theophanes Confessor: Byzantine and Near Eastern History ad 284-813, Oxford, 1997, p. 585; see also Stathakopoulos, Famine and pestilence, p. 384385). Furthermore, Procopius, who indicated that he was present when the plague arrived in Byzantium, mentioned that at the beginning ,apparitions of supernatural beings in human guise of every description were seen by many persons" (Procopius, De Bello Persico II 22, 9-10, tr. Dewing, p. 454-455).

131 Certainly, in 571, see Marius Aventicensis, Chronica, s.a. 571, ed. Favrod, La Chronique de Marius d'Avenches, p. 82-83.

132 Pietri, La Gloire des Martyrs, p. x.

133 Van Dam, Glory of the Martyrs, p. xii.

134 Gregorius Turonensis, Decem Libri Historiarum IV 42, ed. Latouche, Histoire des Francs, p. 228, n. 102; M. Sot, Les Dix livres d'Histoire chez les écrivains carolingiens, "Suppl. Revue archéologique du centre de la France" 13 (1997) p. 325. 


\subsection{Two episodes of inguinal plague in north-eastern Frankish Europe are putatively dated to around 543}

One episode involved Remigius (died in 533), bishop of Reims, who presided over the baptism of Clovis I, King of the Franks ${ }^{135}$. For contemporaries and their first successors, this event was of considerable importance ${ }^{136}$. A large part of the Gallo-Roman elite believed that as long as they were under the tutelage of a German "barbarian" king, at least he should be (non-Arian) Christian. Moreover, the conversion greatly facilitated the relations of the bishops, who were most often Gallo-Roman, with those who held the main temporal power. Faced with long-haired "barbarian" rulers, to retain some remnants of power, the Gallo-Roman aristocracy had almost no other choice to be tonsured and hope to become bishop.

According to Gregory, "When the plague of the groin ravaged the people of First Germany"137, the city of Reims was preserved by prayers made at the tomb of St Remigius ${ }^{138}$. Further, it is mentioned: „Not many days later the celebrated plague (lues [...] memorata) approached the edges of the city"139. Gregory therefore wanted to insist that this epidemic was well known. The extreme dates of this episode can be Remigius' death (533) and the beginning of writing of $G C$ (putatively initiated in 573 , with the greater part written in 587-588, although Gregory continued to work on it until his death) ${ }^{140}$. McCormick proposed a philological analysis of this passage and he emphasized that, if Gregory did not give the name of the bishop of Reims who was in office during the plague epidemic, it was perhaps because the see was vacant (which could have been the case around 543) or because Gregory did not know or wish to give his name ${ }^{141}$. Regarding the last hypothesis, it could be noted that apparently none of the bishops of Reims from 536 until end of the $6^{\text {th }}$ century were elevated to the rank of saint.

135 Gregorius Turonensis, Decem Libri Historiarum II 31.

136 B. Dumézil, Le Baptême de Clovis, Paris 2019.

137 An old Roman province located along the left bank of the middle Rhine valley.

138 Gregorius Turonensis, In Gloria Confessorum 78, tr. Van Dam, Glory of the confessors, p. 59.

139 Gregorius Turonensis, In Gloria Confessorum 78, tr. Van Dam, Glory of the confessors, p. 59.

140 Van Dam, Glory of the confessors, p. xii.

141 McCormick, Gregory of Tours, p. 71-72, n. 168. 
Gregory alluded to a Vita of St Remigius (LH II, 32) which was likely one wrongly attributed to Fortunatus ${ }^{142}$. In this vita, the saint is presented as virtuous and having performed many miracles, both during his lifetime and after his death but there is no mention of plague. In contrast, in later sources, it is well mentioned that Remigius repelled the plague as in the vita of this saint written in the $9^{\text {th }}$ century by Hincmar, archbishop of Reims ${ }^{143}$, or in Flodoard's History of the Church of Reims, which was written in the middle of the $10^{\text {th }}$ century, with the latter author citing only one source: Gregory $^{144}$ !

The second episode related how three holy bishops - two acting from their graves and one who held the episcopal office at that time, Nicetius (c. 525-560s) - drove the plague out of the city of Trier ${ }^{145}$ (in south-western Germany). In VP 17, 4, the passage on the plague is placed without any transition between the mention of the miraculous healing of three possessed men with convulsions and a fish trap being emptied of fish due to a flood and then being miraculously filled following the injunction of the bishop. This positioning, which does not highlight the miracle that would have ended the epidemic, could only be a late insertion.

Nicetius was a virtuous bishop similar to Gallus with whom he shared many things in common, in addition to having saved his city from the bubonic plague. Among the most interesting points on this subject is that Gallus could have become bishop of Trier instead of Nicetius ${ }^{146}$. Moreover, Gregory also specified that from the moment of Nicetius' death ,his soul went in advance (praemisit) to join the Lord" ${ }^{147}$, as was also the same for Gallus, ${ }^{148}$ and Pietri indicated that „Gregory expresses his conception of an immediate retribution promised in heaven to the deceased adorned with holiness" ${ }^{149}$. Moreover, immediately before the mention of the plague epidemic which raged during the episcopate of Gallus,

142 Venanti Honori Clementiani Fortunati, Vita Sancti Remedii, ed. MGH Auct. Ant. 4/2, p. 64-67.

143 Hincmaro, Vita remigii episcopi remensis, ed. MGH SSRM 3, p. 250-341; cf. p. 257, 1. 6-9.

144 Flodoard von Reims, Historia Remensis ecclesiae, ed. MGH SS 36, p. 105, 1. 19.

145 Gregorius Turonensis, Vitae Patrum 17, 4, ed. Pietri, La Vie des Pères, p. 242243, n. 340. Trier is situated less than $200 \mathrm{~km}$ east-north-east of Reims.

146 Gregorius Turonensis, Vitae Patrum 6, 3, ed. James, Life of the Fathers, p. 35-36.

147 Gregorius Turonensis, Vitae Patrum 17, 6, tr. Pietri, La Vie des Pères, p. 248249 , n. 348.

148 Gregorius Turonensis, Vitae Patrum 6, 7, ed. Pietri, La Vie des Pères, p. 85.

149 Gregorius Turonensis, Vitae Patrum 6, 7, tr. Pietri, La Vie des Pères, p. 85, n. 107. 
Gregory recorded ${ }^{150}$, „In his time too there was a great earthquake, which shook the whole town of Clermont. We do not know what the cause of it was, but we do know that no-one was hurt" ${ }^{151}$, while during the outbreak in Trier, Gregory wrote ,in the night, a great noise was heard, like a violent clap of thunder which broke above the bridge over the river, so that one would have thought that the town was going to split in two"152, and the lack of additional indications suggests that there were no injuries or deaths. Although it remains speculative, the passage concerning Gallus could have served as a source of inspiration for that relating to Nicetius.

In $G C$, Gregory devoted two consecutive chapters to two of the bishops (Maximinus and Nicetius) who saved Trier from the plague (GC 91, 92), without mentioning this epidemic. It is the same in the penultimate chapter of $L H$, which also mentions Nicetius: „he was famed far and wide for his good works and his miracles"153. This last chapter is devoted to the "Life" of the abbot Aredius and was written in the same year as his death (591). According to Latouche ${ }^{154}$, it should have been inserted into $V P$. The preface to $V P 17$ indicates that the information on Nicetius that Gregory reported came from his conversations with Aredius, "who was raised by St Nicetius himself and who received clerical orders from him"155. It is not known when Aredius transmitted his information to Gregory, but it was most likely before the second outburst of plague struck Gaul (in 571) ${ }^{156}$. VP 17 would have been composed at the end of $591^{157}$, shortly after $L H X, 29$ (which has however been reworked) but before GC 92158; nevertheless, in this last chapter, the plague is not mentioned, which was either a voluntary omission or an oversight on the part of Gregory, while the plague episode of Reims, as already indicated, is quoted in this book ( $G C 78)$.

The outbreak of Trier can only be dated to the episcopate of Nicetius whose extreme dates are 526 to his death in the 560s, and it

150 However, it is impossible to position this event chronologically.

${ }_{151}$ Gregorius Turonensis, Vitae Patrum 6, 6, tr. James, Life of the Fathers, p. 39.

152 Gregorius Turonensis, Vitae Patrum 17, 4, tr. James, Life of the Fathers, p. 110.

${ }_{153}$ Gregorius Turonensis, Decem Libri Historiarum X, 29, tr. Thorpe, History of the Franks, p. 589.

154 Gregorius Turonensis, Decem Libri Historiarum X 29, ed. Latouche, Histoire des Francs, p. 310, n. 102.

155 Gregorius Turonensis, Vitae Patrum 17, tr. James, Life of the Fathers, p. 104.

156 McCormick, Gregory of Tours, p. 77, n. 178.

157 End 591 according to Pietri, La Vie des Pères, p. 229, n. 322.

158 Pietri, La Vie des Pères, p. xxxvii. 
has been very cautiously suggested that the outbreak could be linked to the plague of 543. Indeed, there would have been only one epidemic of plague in Frankish Europe during this period ${ }^{159}$. The most extreme dates of the episode during which St Remigius saved Reims could be 533-594 (Remigius' death to that of Gregory); however, according to Gregory's works, only the first epidemic outburst of JP would have reached the northern part of Frankish Europe ${ }^{160}$. This element added to the fact that the region of First Germany was not very far from Trier leads to consider that the two epidemics raged during the same period of time ${ }^{161}$.

In documents contemporary to Gregory's writings and in connection with Nicetius, no mention of the epidemic of Trier has ever been found. Fortunatus, who befriended Nicetius, wrote two poems to the latter in which he especially praises his activities as a builder ${ }^{162}$, and in the second, the region that he describes seems idyllic. In addition, two letters written by Nicetius have been preserved, but it should be noted that the sanitary situation was not their subject ${ }^{163}$.

\subsection{Short examination of the rhetorical structure of the passages mentioning plague}

In Gregory's corpus, the beginning of the passages mentioning the plague episodes around 543, follows approximately the same lexical construction. The standard sentence is as follows: When (cum) the inguinal plague (or when the epidemic that we call inguinaria)... follows the name of the region ravaged by the outbreak (except in GM 50,3, where the region is cited before the mention of plague) and then the name of the saint through whose intercession the people escaped disease (or information relating to the saint) ${ }^{164}$. The terms retained appear in bold letters:

159 Cf. Gregorius Turonensis, Vitae Patrum 17, 4, James, Life of the Fathers, p. 110, n. 9; Pietri, La Vie des Pères, p. 242, n. 340; McCormick, Gregory of Tours, p. 73.

160 McCormick, Gregory of Tours, p. 39, 70, 73.

161 McCormick, Gregory of Tours, p.70-75.

162 Venantius Fortunatus, Opera poetica III 11-12, ed. MGH Auct. Ant. 4/1, p. 63-65.

163 Nicetius (trevirensis), Epistolae Austrasicae 7-8, ed. MGH Epp. 3, Epistolae 3, Epistolae Merowingici et Karolini Aevi III, p. 118-122.

164 See also McCormick, Gregory of Tours, p. 62. 
Cum autem lues illa quam inguinariam vocant per diversas regiones desaeviret et maximae tunc Arelatensim provintiam depopularet, sanctus Gallus $[\ldots]^{\prime \prime 165}$.

„Huius tempore cum lues illa quam inguinariam vocant per diversas regiones desaeviret et maxime tunc Arelatensim provinciam depopularet, sanctus Gallus $[\ldots]^{166}$.

Cum autem ad Arvernam regionem lues illa inguinaria adveniret, quae sancti Galli episcopi $[\ldots]^{167}$.

Cum autem lues inguinaria Treuericum populum in circuitu civitatis valde vastaret, et sacerdos Dei [St Nicetius] [...] ${ }^{168}$.

[...] cum lues inguinaria populum primae Germaniae devastaret. Cum autem omnes terrerentur huius cladis auditu, concurrit Remensium populus ad sancti sepulchrum [of St Remigius] [...] $]^{169}$.

These analogous construction modes do not imply that all of the passages were written at the same time but suggest that the first written certainly served as a model for all of the others. In Gregory's works, two other sentences, which relate to the plague of 571, are close to this typical construction, but in $V P$ 9, 2, there is no geographical mention, whereas in $V J$ $46 \mathrm{a}$, the conjunction of time cum, which is frequently translated as "when", is absent. However, the similarities between the plague mentions around 543 and two of the four chapters focusing on the plague of 571 might not be due to chance.

In all of the passages mentioning the plague around 543, except in the first sentence with "inguinal", there is no further indication of symptoms or clinical signs. The epidemic could be mentioned again in the remainder of the text but without a qualifier, such as lues in $V P$ 6, 6 and $L H \mathrm{IV}, 5$ or plaga, which would have been used both by Gregory's mother and the envoy of the sky ${ }^{170}$. This last substantive, which, in classical Latin, signifies blow or wound, would not have designated an epidemic until a later period. It is for example present in this last

165 Gregorius Turonensis, Vitae Patrum 6, 6, ed. MGH SSRM 1/2, p. 234, 1. 15-16.

166 Gregorius Turonensis, Decem Libri Historiarum IV 5, ed. MGH SSRM 1/1, p. $138,1.8-10$.

167 Gregorius Turonensis, De Gloria Martyrum 50, ed. MGH SSRM 1/1, p. 73, 1. 34, p. $74,1.1$.

168 Gregorius Turonensis, Vitae Patrum 17, 4, ed. MGH SSRM 1/2, p. 281, 1. 13-4.

169 Gregorius Turonensis, In Gloria Confessorum 78, ed. MGH SSRM 1/2, p. 345, 1. 21, p. 346, 1. 1-2.

170 Gregorius Turonensis, De Gloria Martyrum 50, 3. 
acceptance in the Vulgate ${ }^{171}$. In GC 78, the mention of "celebrated lues" certainly refers to that stopped by Gallus' intercession. Moreover, Gregory could also use terms meaning disease and not epidemic, which may suggest that he considered that the intensity of the outbreak was relatively low (infirmitate in $V P$ 6, 6 and LH IV, 5 or morbus in VP 17, 4).

\subsection{Studies of ancient DNA leave room for doubt}

An archaeological inventory of mass graves during the period around JP in territory corresponding approximatively to the Roman Empire at its greatest extension has been compiled by McCormick ${ }^{172}$. This study shows that numerous great mortality crises occurred in the $6^{\text {th }}$ and $7^{\text {th }}$ centuries. However, it is very difficult to relate these mass burials to a particular episode of plague as dating remains imprecise. Moreover, ancient DNA (aDNA) investigations do not always provide absolute proof. From teeth collected from human remains found generally, in double or greater burials and dated to the first plague pandemic period, aDNA of $Y$. pestis has been detected in rare cases and frequently in a very small amount in a given site. All of the genomic sequences issued from $Y$. pestis from this period have been found only in Western Europe (Britain, Germany, France and Spain) ${ }^{173}$. To date, no sequence can be attributed without too much uncertainty to the epidemics of the 540s. All the $Y$. pestis genomes recovered from Gaul are clearly not associated with the initial outbreak in the 540s but are related to subsequent outbreaks. No Y. pestis genome from Germany can be connected with certainty to the 540s, and molecular analysis of the sequence from Valencia (Spain) suggests an association with a post-540s episode. Yersinia pestis genomes from an English cemetery with archaeological dating (around 500-550) ${ }^{174}$ could be linked to the first occurrence

${ }^{171}$ Lev. 13:2; 1Reg. 22:35.

172 M. McCormick, Tracking mass death during the fall of Rome's empire (I), "Journal of Roman Archaeology" 28 (2015) p. 325-357; M. McCormick, Tracking mass death during the fall of Rome's empire (II): A first inventory of mass graves, "Journal of Roman Archaeology" 29 (2016) p. 1004-1046.

${ }^{173}$ See lists in M. Keller - M.A. Spyrou - C.L. Scheib, Ancient Yersinia pestis genomes from across Western Europe reveal early diversification during the First Pandemic (541-750), "Proceedings of the National Academy of Sciences" 116 (2019) p. S38-S44, Table S1.

${ }^{174}$ Keller - Spyrou - Scheib, Ancient Yersinia pestis genomes from across Western Europe, p. S38-S44, Table S1. 
of the plague in Western Europe or even could be earlier to this episode. However, according to textual sources, the first records of bubonic plague in England date to the $660 \mathrm{~s}^{175}$; nevertheless, for the $6^{\text {th }}$ century concerning this area, documentary sources are very rare. Furthermore, in Britain, before the JP period, multiple burials were already relatively frequent, therefore they do not necessarily have to be correlated with epidemics ${ }^{176}$. In a recent phylogenetic analysis, $Y$. pestis sequences dated around to the JP period form a strongly supported monophyletic group including a sample from an English grave. Moreover, the latter sequence is a sister group of a clade composed of all other ancient $Y$. pestis genomes of the first plague pandemic period used in this study ${ }^{177}$. In addition, the sister group of all of these sequences is an ancient $Y$. pestis genome from the Tian Shan region, Kazakhstan, dated from the $2^{\text {nd }}$ to $3^{\text {rd }}$ century ${ }^{178}$. These analyses suggest that $Y$. pestis genomes could be phylogenetically related, regardless of whether human beings have been victims of outbreaks or sporadic individual infections. In the English cemetery, the search for $Y$. pestis genomes was performed on one tooth per individual, and approximately $18 \%$ of the samples were considered positive after sequencing ${ }^{179}$. This fairly high yield could suggest a plague outbreak; however, as already underlined, pre-Justinianic human infections cannot be fully ruled out. This raises many questions. Although these data remain speculative, some strains of $Y$. pestis detected could be mainly present in rodent host reservoirs, and they could either be very benign to humans or be able to induce disease but only very rarely affect humans ${ }^{180}$. Since the mid- $18^{\text {th }}$ century, mild forms of bubonic plague

175 J. Maddicott, Plague in seventh-century England, in: Plague and the End of Antiquity: The Pandemic of 541-750, ed. L.K. Little, Cambridge 2007, p. 171-214.

176 L. Mordechai - M. Eisenberg - T. Newfield, The Justinianic Plague: An inconsequential pandemic?, "Proceedings of the National Academy of Sciences" 116 (2019) p. 25546-25554.

177 Keller - Spyrou - Scheib, Ancient Yersinia pestis genomes from across Western Europe, p. 12366.

178 Keller - Spyrou - Scheib, Ancient Yersinia pestis genomes from across Western Europe, p. 12366. See also M. Keller - M.A. Spyrou - M. McCormick, Ancient Yersinia pestis genomes provide no evidence for the origins or spread of the Justinianic Plague, "bioRxiv" 819698 (31 October 2019).

179 Keller - Spyrou - Scheib, Ancient Yersinia pestis genomes from across Western Europe, p. S39, Table S1.

180 Sporadic cases of plague are reported in endemic regions and are associated with activities in rural areas (E. Bertherat, Plague around the world, 2010-2015, "Weekly Epidemiological Record" 91 (2016) p. 89-93). 
have been observed by physicians, most often in regions where the disease is endemic ${ }^{181}$. Symptoms of pestis minor include, among others, swollen lymph nodes that subside within a week ${ }^{182}$. If ailments of this type were present, even at a low rate, in Gaul in the $540 \mathrm{~s}$, it could have retrospectively influenced Gregory in the choice of the name to be given to the diseases that occurred at the time. Future studies of aDNA could provide information about the origin of $Y$. pestis strains present in Western Europe in the mid- $6^{\text {th }}$ century and potentially before, as well as allow to determine their potential malignancy.

\section{Discussion and conclusion}

This article suggests that the length of the passages mentioning the plague and the references to lues inguinaria do not necessarily indicate with certainty the presence of bubonic plague in a given area. Mordechai et al. ${ }^{183}$ counted the number of words referring to the JP stricto sensu in works of various authors but not those of Gregory, who, with 779 words, comes in fourth among authors who quantitatively paid the most attention to this episode. However, in Gregory's works, textual repetitions make up $49 \%$ of the total, and lexical structures reporting miracles performed during plague episodes have many similarities to each other. Studies of epidemics of plague in Frankish Europe around 543 are often subject to circular reasoning, as it is mentioned lues inguinaria this would necessarily mean that there had been episodes of inguinal plague, and as the intervention of Gallus can be potentially dated, other plague outbreaks with uncertain chronological positioning are linked to the previous one. Gregory seems to have been the first author to use the expression lues inguinaria ${ }^{184}$ and after the records putatively around 543, the subsequent mentions of inguinal plague would relate to the epidemic of $571^{185}$. As Gregory would probably not have started to write these works before his

181 C. Lynteris, Pestis Minor: The History of a Contested Plague Pathology, "Bulletin of the History of Medicine" 93 (2019) p. 55-81.

182 L.M. Bush - M.T. Vazquez-Pertejo, Plague and other Yersinia infections, Merck Manual Profess, w: https://www.merckmanuals.com/ (accessed 05.01.2021).

183 Mordechai - Eisenberg - Newfield, The Justinianic Plague: An inconsequential pandemic?, p. 25546-25554.

184 Brepols Cross-Database Search Tool enables users to consult and search the different full-text Latin databases of Brepols Latin.

185 Gregorius Turonensis, Vitae Patrum 6, 2. 
appointment to the bishopric of Tours, it was therefore only retrospectively that he would have used these terms possibly following information from the Roman Empire. The a posteriori construction of the paragraphs on the plague around 543 could also aim, in addition to discrediting Bishop Cautinus even if it is partly related, to reinforce the prestige of Gregory's family (this concerns his uncle, his mother and also the "family saints"), as well as that of virtuous Gallo-Roman bishops (in addition to Gallus, once again, Nicetius and Remigius) who had succeeded in protecting their episcopal city or even their diocese at a time when Constantinople and Italy were ravaged by the epidemic. Analysis of Gregory's works also shows that bishops who were subsequently sanctified, whether Gallus or Nicetius, always had to be "assisted" by "dead saints". For this period, in Gregory's books, in Auvergne and Reims, there is no mention of miraculous healing of plague victims, which could have added trustworthiness to the text, unlike the mentions of "immunization of the soil and its inhabitants"186 thanks to the virtues of the saints. Indeed, two areas surrounded by the plague (Clermont and Reims) completely escaped the epidemic, while in the third (Trier) "As soon as this voice had been heard, the malady ceased, and from that moment no-one else died"187; however, there is no explicit mention of miraculous healings of individuals. Otherwise, in his accounts, Gregory generally tended to favour mentions of the miracles performed by the "good" bishops rather than their pastoral activity $^{188}$. In addition, during the episodes of plague around 543, Gregory makes no mention of interventions by secular physicians or even charlatans.

This article also demonstrates the interest attached to multiple approaches and to contextualizing the different elements that are analysed, e.g., the dates of writing, repetitions in texts, kinship ties between bishops, spatiotemporal data, durations of boat trips and periods of navigation, estimation of the average rate of progression of the plague, other infected areas at the time, aDNA data, etc. However, at least two other fields of research possibly related to the subject of this article have not been mentioned. Infectious agents other than $Y$. pestis could be responsible for mortality crises during the JP period ${ }^{189}$, such Plasmodium which is

186 B. Beaujard, Le culte des saints et la lutte contre la peste dans la Gaule du VIe siècle, in: Romanité et cité chrétienne. Permanences et mutations, intégration et exclusion $d u I^{e r}$ au VIe siècle, ed. F. Prévôt, Paris 2000, p. 340.

187 Gregorius Turonensis, Vitae Patrum 17, 4, tr. James, Life of the Fathers, p. 111.

188 Gregorius Turonensis, Vitae Patrum 7, ed. Pietri, La Vie des Pères, p. 96, n. 118.

189 McCormick, Tracking mass death during the fall of Rome's empire, (I), p. 325-357. 
responsible for malaria ${ }^{190}$. Moreover, the climate could have also played a determining role, since the two coldest years in Paris from 525 to 565 were 543 and $545^{191}$. This cooling, which was certainly due to volcanic eruptions in 536 and $540^{192}$, could have had serious health consequences $^{193}$. This fact allows us to give some credit to Gregory. The mentions of inguinal plague that he makes could in fact be related to other diseases raging at this time, and it should be remembered that he was still in early childhood and that those around him were only able to report the facts to him later in a distorted way. Reading Gregory, the plague outbreaks around 543 appear to have been a very important event involving, among others, the city of Clermont, its bishop, who was incidentally Gregory's uncle, and his own mother, but internal allusion and cross-references concerning these events are very rare, reinforcing the hypothesis of late fictitious additions. Furthermore, even if other sources are scarce, none of Gregory's contemporaries living in Frankish Europe corroborated his claims. The most important contradiction to Gregory's mentions is provided by the Vita of Caesarius of Arles, which does not mention any epidemic in the region of Arles from at least c. 496 to $547^{194}$. Martin Heinzelmann rightly mentioned that, for the Early Middle Ages, it is generally not necessary to separate the discourses considered historical from the hagiographical ${ }^{195}$, and in this article, it is shown that at least at the level of analysis of the mentions of plague, only comparison between the two types of works may provide fruitful results ${ }^{196}$.

190 E.g., for Faure - Jacquemard, L'émergence du paludisme en Gaule, p. 55-70; Faure, Datation de l'introduction du paludisme en Provence, p. 378-406; Faure, The Vita, the first testimony, p. 217-225.

191 P.N. Peregrine, Climate and social change at the start of the Late Antique Little Ice Age, "Holocene" 30 (2020) p. S11; see also U. Büntgen - V.S. Myglan - F.C. Ljungqvist, Cooling and societal change during the Late Antique Little Ice Age from 536 to around 660 AD, "Nature Geoscience" 9 (2016) p. 231-236.

192 A. Arjava, The Mystery Cloud of $536 \mathrm{CE}$ in the Mediterranean Sources, "Dumbarton Oaks Papers" 59 (2005) p. 73-94.

193 T.P. Newfield, Mysterious and mortiferous Clouds: The climate cooling and disease burden of Late Antiquity, "Late Antique Archaeology" 12 (2018) p. 271-297.

194 Delage, Vie de Césaire d'Arles.

195 M. Heinzelmann, Hagiographischer und historischer Diskurs bei Gregor von Tours?, in: Aevum inter utrumque, ed. M. van Uytanghe - R. Demeulenaere, The Hague 1991, p. 241-242.

196 E.g., on this subject, the contribution of the Vitae Caesarii episcopi Arelatensis seems to us decisive (see ed. Delage). 
Finally, as already mentioned, since 2019, authors have developed a revisionist view of the first pandemic, suggesting that the overall death rate was greatly overestimated and therefore that the direct mid- to long-term effects were inconsequential ${ }^{197}$. Concerning the first episodes of plague in Frankish Europe mentioned by Gregory, the present article seems likely to corroborate their hypothesis, not that the bubonic plague epidemics were of low intensity but that they did not occur at all.

Acknowledgements: The author would like to thank the referees for their valuable comments which helped improve the manuscript.

\section{Did the Justinianic Plague Truly Reach Frankish Europe around 543 AD?}

(summary)

This article focuses on the episodes of bubonic plague recorded around 543 AD in Frankish Europe, which upon rereading, appear doubtful. Beginning in 541 and for two centuries, the so-called first plague pandemic ravaged the Mediterranean area over several successive epidemic outbursts. The first mentions concern Egypt. The plague then spreads northward to Constantinople and almost concomitantly or shortly afterward moves westward until it reaches Western Europe. For this last region, the main source is Bishop Gregory of Tours, who, in both his historical and his hagiographic writings, provides numerous data on the first outbreaks that raged in Frankish Europe referring to the Justinianic Plague, episodes to which he was a contemporary (even if for the first, he was still in early childhood). According to Gregory, around 543, bubonic plague ravaged several areas under Frankish rule. However, among others, intertextual, contextualized and chronological analyses strongly suggest that these events could be, in fact, fictional. Gregory seems to have wanted to balance, the behaviour of two bishops of Clermont that were totally opposed during epidemics of plague. In the episode of 571, when the plague struck the episcopal city, the unworthy Bishop Cautinus, to escape disease, fled the city in cowardice. In the previous episode, through the intercession of Gregory's paternal uncle, the virtuous Gallus, who was the immediate predecessor of Cautinus and a saint specific to the paternal branch, the city, and probably the diocese, was spared from the plague. Other references to similar events in which, through saints, the plague is driven out, or territories are protected from it are also dated arbitrarily from this last period. Furthermore, unlike the 571 episode, the plague around 543 was never considered a punishment for sin; moreover, no miraculous healing of plague patients is recorded at least in Clermont and Reims. Contemporary texts from other authors of Frankish Europe, although rare, never mention any epidemic around 543, especially

197 Mordechai - Eisenberg - Newfield, The Justinianic Plague: An inconsequential pandemic?, p. 25546-25554; Mordechai - Eisenberg, Rejecting catastrophe, 3-50; M. Meier, The 'Justinianic Plague': An “Inconsequential Pandemic”? A Reply, "Medizinhistorisches Journal” 55/2 (2020) p. 172-199. 
the Vita of Caesarius of Arles, which was written shortly after the death of this bishop (from 542 to 547-549) by several hagiographers, while two of Gregory's texts, which are repeated almost verbatim, indicate that the province of Arles was the most-affected region. This underscores the decisive contribution that hagiographic texts can make in the analysis of facts considered to be historical.

Keywords: Justinianic plague; Gregory of Tours; 543 AD; inguinal plague; Gaul; Frankish Europe

\section{Bibliography}

\section{Sources}

Cassiodorius, Variae, ed. Th. Mommsen, MGH Auct. Ant. 12, Berolini, 1894.

Chronicorum Caesaraugustanum reliquae, ed. Th. Mommsen, MGH Auct. Ant. 11/2, Berolini 1904.

Flodoard von Reims, Historia Remensis ecclesiae, ed. M. Stratmann, MGH SS 36, Hannover 1998.

Gregorius Turonensis, Liber in Gloria Martyrum, ed. L. Pietri, La Gloire des Martyrs, Paris 2020.

Gregorius Turonensis, Liber Vitae Patrum, ed. L. Pietri, La Vie des Pères, Paris 2016.

Gregorius Turonensis, Opera, ed. B. Krush, MGH SSRM 1/1-2, Hannoverae 1969, w: https://www.dmgh.de/ (accessed 05.01.2021).

Hincmaro, Vita remigii episcopi remensis, ed. B. Krusch, MGH SSRM 3, Hannoverae 1896. Marcellini V.C., Chronica, ed. Th. Mommsen, MGH Auct. Ant. 11/2, Berolini 1894.

Marius Aventicensis, Chronica, ed. J. Favrod, La Chronique de Marius d'Avenches (455-581). Texte, traduction et commentaire, Lausanne 1993.

Nicetius (trevirensis), Epistolae Austrasicae, ed. W. Gundlach, MGH Epp. 3, Epistolae 3, Epistolae Merowingici et Karolini Aevi III, Berolini 1892.

Procopius, De Bellis, tr. and ed. H.B. Dewing, History of the wars, Loeb Classical Library, Cambridge 1914.

Venantius Fortunatus, Opera poetica III, ed. F. Leo, MGH Auct. Ant. 4/1, Berolini 1881. Victor Tonnennensis, Chronica, ed. Th. Mommsen, MGH Auct. Ant. 11/2, Berolini 1894. Vita Caesarii episcopi Arelatensis, ed. and tr. M.-J. Delage, Vie de Césaire d'Arles, Paris 2010.

\section{Litterature}

Albright W.F., The Proto-Sinaitic inscriptions and their decipherment, Harvard 1969. Arjava A., The Mystery Cloud of 536 CE in the Mediterranean Sources, "Dumbarton Oaks Papers" 59 (2005) p. 73-94. 
Beaujard B., Le culte des saints et la lutte contre la peste dans la Gaule du VIe siècle, in: Romanité et cité chrétienne. Permanences et mutations, intégration et exclusion du $I^{e r}$ au VI siècle, ed. F. Prévôt, Paris 2000, p. 335-342.

Benedictow O.J., The black death (1346-1353). The complete history, Woodbridge 2004.

Bertherat E., Plague around the world, 2010-2015, "Weekly Epidemiological Record" 91 (2016) p. 89-93.

Biraben J.-N., Les hommes et la peste en France et dans les pays européens et méditerranéens, v. 1, Paris 1975.

Bonnet M., Le latin de Grégoire de Tours, Paris 1890.

Brepols Cross-Database Search Tool, w: http://www.brepolis.net/ (accessed 05.01.2021). Büntgen U. - Myglan V.S. - Ljungqvist F.C., Cooling and societal change during the Late Antique Little Ice Age from 536 to around 660 AD, "Nature Geoscience" 9 (2016) p. 231-236.

Bush L.M. - Vazquez-Pertejo M.T., Plague and other Yersinia infections, Merck Manual Profess, w: https://www.merckmanuals.com/ (accessed 05.01.2021).

Carozzi C., Grégoire de Tours historien?, in: Faire l'événement au Moyen Âge, ed. C. Carozzi - H. Taviani-Carozzi, Aix-en-Provence 2007, p. 201-215.

Casson L., Ships and Seamanship in the Ancient World, Princeton 2014.

Croke B., The Chronicle of Marcellinus: a translation and commentary, Oxford 2017.

Dalton O.M., The History of the Franks, v. 2, Oxford 1927.

Damgaard P.B. - Marchi N. - Rasmussen S., 137 ancient human genomes from across the Eurasian steppes, "Nature" 557/7705 (2018) p. 369-374.

D'Hérouville P., La culture classique de saint Grégoire de Tours, "Études des Pères de la Compagnie de Jésus" 126 (1911) p. 787-804.

Dumézil B., Le Baptême de Clovis, Paris 2019.

Dumézil B., La reine Brunehaut, Paris 2008.

Dupouy E., Le Moyen âge medical, Paris 1888.

Eisenberg M. - Mordechai L., The Justinianic Plague: An Interdisciplinary Review, "Byzantine and Modern Greek Studies" 43 (2019) p. 156-180.

Eisenberg M. - Mordechai L., The Making of the Plague Concept: The Justinianic Plague, Global Pandemics, and Writing History, "American Historical Review" 125 (2020) p. 1632-1667.

Faure É. - Jacquemard N., L'émergence du paludisme en Gaule: analyse comparée des écrits de Sidoine Apollinaire et Grégoire de Tours, "Caesarodunum" 44-45 (2014) p. 55-70.

Faure É., Datation de l'introduction du paludisme en Provence, "Provence Historique" 67 (2017) p. 378-406.

Faure É., The Vita, the first testimony of the settlement of malaria in Provence, in: Caesarius of Arles and the Five Continents, v. 2, ed. ASP, Venelles 2018, p. 217-225.

Foulke W.D., Paul the Deacon, History of the Lombards, Philadelphia 1907.

Giesebrecht W., Gregor von Tours, Zehn Bücher Geschichten, v. 1, Berlin 1851. 
Harper K., Pandemics and passages to Late Antiquity: Rethinking the plague of c. 24970 described by Cyprian, "Journal of Roman Archaeology” 28 (2015) p. 223-260.

Harper K., The Fate of Rome: Climate, Disease, and the End of an Empire, Princeton 2017. Haydock G.L., The Holy Bible; translated from the Latin vulgate, New York 1855.

Heijmans M., Arles durant l'antiquité tardive: de la duplex Arelas à l'urbs genesii, Rome 2004.

Heinzelmann M., Gregory of Tours: History and Society in the Sixth Century, tr. Ch. Carroll, Cambridge 2001.

Heinzelmann M., Hagiographischer und historischer Diskurs bei Gregor von Tours?, in: Aevum inter utrumque, ed. M. van Uytanghe - R. Demeulenaere, The Hague 1991, p. 237-258.

Heinzelmann M., Structures typologiques de l'histoire d'après les histoires de Grégoire de Tours, "Recherches de Science Religieuse" 92 (2004) p. 569-596.

James E., Gregory of Tours, Life of the Fathers, Liverpool 2007.

Jones A., Death and Afterlife in the pages of Gregory of Tours: Religion and society in Late Antique Gaul, Amsterdam 2020.

Kearns A.L., A Plague in a crisis: Differential diagnosis of the Cyprian plague and its effects on the Roman Empire in the third century CE, University of Arizona 2018 (Thesis, Master of arts).

Keller M. - Spyrou M.A. - McCormick M., Ancient Yersinia pestis genomes provide no evidence for the origins or spread of the Justinianic Plague, "bioRxiv" 819698 (31 October 2019).

Keller M. - Spyrou M.A. - Scheib C.L., Ancient Yersinia pestis genomes from across Western Europe reveal early diversification during the First Pandemic (541-750), "Proceedings of the National Academy of Sciences" 116 (2019) p. 12363-12372.

Kenrick F.P., The book of Job, and the Prophets, tr. from the Vulgate, a revised ed. of the Douay version, Baltimore 1859.

Klingshirn W.E., Caesarius of Arles: The making of a Christian community in Late Antique Gaul, Cambridge 2014.

Kulikowski M., Plague in Spanish Late Antiquity, in: Plague and the End of Antiquity: The Pandemic of 541-750, ed. L.K. Little, Cambridge 2007, p. 150-170.

Latouche R., Grégoire de tours, Histoire des Francs, Paris 2005.

Little L.K., Plague and the End of Antiquity: The Pandemic of 541-750, Cambridge 2007.

Lynteris C., Pestis Minor: The History of a Contested Plague Pathology, "Bulletin of the History of Medicine" 93 (2019) p. 55-81.

Maddicott J., Plague in seventh-century England, in: Plague and the End of Antiquity: The Pandemic of 541-750, ed. L.K. Little, Cambridge 2007, p. 171-214.

Mâle É., L'art religieux du XII siècle en France: étude sur les origines de l'iconographie du moyen âge, v. 1, Paris 1922.

Mango C. - Scott R., The Chronicle of Theophanes Confessor: Byzantine and Near Eastern History ad 284-813, Oxford 1997. 
Marignan A., La Médecine dans l'Eglise au sixième siècle, Paris 1887.

Marlier S., Le port d'Arles à l'époque romaine: un port fluviomaritime, "Archaeonautica" 18 (2014) p. 62-63.

Martinez D., De la cité Arverne au diocèse de Clermont: Topographie ecclésiale, fortifications et peuplements de l'Auvergne entre Antiquité tardive et haut Moyen Âge (Ve-Xe siècles): une approche archéologique, Université Clermont Auvergne 2017 (Thèse d'Histoire).

McCormick M., Bateaux de vie, bateaux de mort. Maladie, commerce, transports annonaires et le passage économique du bas-Empire au Moyen Âge, in: Morfologie sociali e culturali in Europa fra tarda Antichità e alto medioevo (Spoleto, 3-9 aprile 1997), Settimane di studio del centro italiano di studi sull'alto medioevo 45/1, Spoletto 1998, p. 35-122.

McCormick M., Gregory of Tours on sixth-century plague and other epidemics, "Speculum" 96 (2021) p. 38-96.

McCormick M., Tracking mass death during the fall of Rome's empire (I), "Journal of Roman Archaeology" 28 (2015) p. 325-357.

McCormick M., Tracking mass death during the fall of Rome's empire (II): A first inventory of mass graves, "Journal of Roman Archaeology" 29 (2016) p. 1004-1046.

Meier M., The 'Justinianic Plague': The economic consequences of the pandemic in the eastern Roman empire and its cultural and religious effects, "Early Medieval Europe" 24 (2016) p. 267-292.

Meier M., The 'Justinianic Plague': An "Inconsequential Pandemic”? A Reply, "Medizinhistorisches Journal" 55/2 (2020) p. 172-199.

Mordechai L. - Eisenberg M. - Newfield T., The Justinianic Plague: An inconsequential pandemic?, "Proceedings of the National Academy of Sciences" 116 (2019) p. 25546-25554.

Mordechai L. - Eisenberg M., Rejecting catastrophe: The case of the Justinianic Plague, "Past Present" 244 (2019) p. 3-50.

Newfield T.P., Mysterious and mortiferous Clouds: The climate cooling and disease burden of Late Antiquity, "Late Antique Archaeology” 12 (2018) p. 271-297.

Newfield T.P., The Climate Downturn of 536-50, in: The Palgrave Handbook of Climate History, ed. S. White - C. Pfister - F. Mauelshagen, London 2018, p. 447-493.

Orbis: The Stanford Geospatial Network Model of the Roman World, w: https://orbis. stanford.edu/ (accessed 05.01.2021).

Peregrine P.N., Climate and social change at the start of the Late Antique Little Ice Age, "Holocene" 30 (2020) p. 1643-1648.

Pietri L., Les médecins dans la Gaule chrétienne du Ve au VII siècle: rôle et réputation, “Annales Littéraires de l’Université de Besançon” 404 (1989) p. 343-357.

Pirenne H., Le commerce du papyrus dans la Gaule mérovingienne, "Comptes Rendus des Séances de l'Académie des Inscriptions \& Belles-lettres” 72 (1928) p. 178-191. 
Prosopographie chrétienne du Bas-empire 4: La Gaule chrétienne (314-614), v. 1-2, ed. L. Pietri - M. Heijmans, Paris 2013.

Pummer R., Early Christian Authors on Samaritans and Samaritanism: Texts, Translations and Commentary, Tübingen 2002.

Riché P., Problèmes de démographie historique du Haut Moyen Age (Ve-VIIIe siècles), "Annales de démographie historique" 3 (1966) p. 37-55.

Sessa K., The New Environmental Fall of Rome: A Methodological Consideration, "Journal of Late Antiquity" 12 (2019) p. 211-255.

Slack P., Plague: a very short introduction, New York 2012.

Sot M., Les Dix livres d'Histoire chez les écrivains carolingiens, "Suppl. Revue archéologique du centre de la France" 13 (1997) p. 319-329.

Stathakopoulos D., Famine and pestilence in the Late Roman and Early Byzantine Empire: A systematic survey of subsistence crises and epidemics, Aldershot 2016.

Thorpe L., Gregory of Tours: History of the Franks, Baltimore 1974.

Van Dam R., Gregory of Tours, Glory of the confessors, Liverpool 2004.

Van Dam R., Gregory of Tours, Glory of the Martyrs, Liverpool 2004.

Van Dam R., Saints and their Miracles in Late Antique Gaul, Princeton 2006.

Verdon J., Grégoire de Tours: le père de l'histoire de France, Roanne 1989.

White L.A. - Mordechai L., Modeling the Justinianic Plague: Comparing hypothesized transmission routes, "PLoS One" 15/4 (2020) p. e0231256.

Yue R.P. - Lee H.F. - Wu C.Y., Navigable rivers facilitated the spread and recurrence of plague in pre-industrial Europe, "Scientific Reports" 6 (2016) p. 34867.

Yue R.P. - Lee H.F. - Wu C.Y., Trade routes and plague transmission in pre-industrial Europe, "Scientific Reports" 7 (2017) p. 12973. 